\title{
Karyomorphological Studies of Six Species of Turkish Muscari (Asparagaceae)
}

\author{
Tuna Uysal ${ }^{1 *}$, Meryem Bozkurt ${ }^{1}$, Ela Nur Şimşek Sezer ${ }^{1}$, Ahmet Aksoy $^{2}$ and \\ Kuddisi Ertuğrul ${ }^{1}$
}

${ }^{1}$ Science Faculty, Department of Biology, Selçuk University, Konya, Turkey

${ }^{2}$ Science Faculty, Department of Biology, Akdeniz University, Antalya, Turkey

Received July 18, 2021; accepted August 2, 2021

\begin{abstract}
Summary In this study, chromosome length, karyomorphology and chromosome asymmetry of six Turkish Muscari species; Muscari muglaensis, M. nazimiyensis, M. pallens, M. pamiryigidii, M. inundatum and M. fatmaceranie were evaluated. The somatic chromosome number of all examined taxa was determined as $2 n=18$. The basic chromosome number was $x=9$. Chromosomes consist of metacentric, submetacentric, and subtelocentric chromosomes. This is the first report on chromosome number and morphology for five of the six taxa studied. Studies on the karyotype and chromosomal diversity of Muscari may provide insight into taxonomic relationships and differences within the genus.
\end{abstract}

Keywords Chromosome number, Endemic, Karyomorphology, Karyotype, Muscari, Turkey.

Muscari is a genus of bulbous plants belonging to the Asparagaceae family. The genus has a wide distribution in the Mediterranean basin, Central and Southwest Europe, the Caucasus, Southwest Asia and Central Asia (Speta 1998, Jafari et al. 2008). While the genus is represented by 77 species in the world (Eker and Yildirim 2021), it is represented by 51 species, 34 of which are endemic in Turkey (Davis and Stuart 1984, Eker 2012, Demirci et al. 2013, 2014, 2019, Kaya and Rastgeldi 2014, Pirhan et al. 2014, Y1ldırım 2015, 2016, P1nar et al. 2018, Doğu and Uysal 2019, Eker 2019a, b, Eker et al. 2019, Eroğlu et al. 2019, Eroğlu and Pınar 2019, Yıldırımlı and Kılıç 2019, Eker et al. 2020, Eker and Kandemir 2020, Eker and Yildırım 2021, Eker 2021). When considering the density of the species number and endemism rate in Muscari, Turkey is one of the main differentiation and gene centers (Yıldırım 2016, Böhnert and Lobin 2017, Doğu and Uysal 2019). The situation of the genus Muscari is highly controversial both taxonomically and karyologically (Speta 1989, 1998, Davis and Stuart 1980, 1984, Karlén 1991, Azizi et al. 2016). Numerous karyological studies have been performed on Muscari to date, and these, combined with morphological evidence, have provided most of the taxonomic data for the genus (Garbari, 1966, 1972, 1973, Stuart 1970, Bentzer 1972, Ruiz-Rejón 1978, Ruiz-Rejón and Oliver 1978, Karlén 1984a, b, Ruiz-Rejón et al. 1985, 1986). The infrageneric classification of Muscari is an unresolved problem. In fact, taxonomic divisions within the genus were supported by karyological data by Garbari

\footnotetext{
* Corresponding author, e-mail: tuysal@selcuk.edu.tr DOI: $10.1508 /$ cytologia. 86.351
}

and Greuter (1970). Although most taxa of the genus are diploid, there are also some polyploid taxa (Stuart 1970, Karlén 1984b, Dalgıç 1991, Özhatay and Johnson 1996, Johnson and Brandham 1997, Demirci Kayıran and Özhatay 2017, Bozkurt 2020, Kiran et al. 2020a, b). Chromosome number and chromosome morphology are increasingly used in plant taxonomy (Eroğlu et al. 2013). Chromosomes can reveal all cytogenetic possibilities for understanding the boundaries, affinities and evolution of taxa. Karyotype is the characterization of the number, size and morphology of the chromosome set of a species. Karyotype studies are important in determining karyotypic polymorphism and inter- and intra-species cytogenetic variation and evolution (Marques de Resende 2017). The most important aim of this report is to complete lacking chromosomal information of Turkish Muscari species which are published in soon. Therefore, this study includes the chromosomal number and karyomorphological reports of six Muscari taxa which are M. muglaensis, M. nazimiyensis, M. pallens, M. pamiryigidii, M. inundatum and M. fatmacereniae.

Materials and methods

The bulbs of the studied Muscari species were collected from natural areas of Turkey (Table 1). The bulbs of the examined taxa were germinated by placing them in foams prepared properly in water. Chromosome counts were performed using the squashing technique at the somatic metaphase (Goldblatt 1996). Root tips germinated from bulbs were pretreated with 8-hydroxyquinoline for $8 \mathrm{~h}$ at $4^{\circ} \mathrm{C}$. After pretreatment, root tips were placed in Carnoy fixative and fixed at low temperature for 
Table 1. Taxa studied and localities.

\begin{tabular}{|c|c|c|}
\hline Subgenus & Taxa & Locality \\
\hline Leopoldia & M. muglaensis Eker, H. Duman \& Yıldırım & $\begin{array}{l}\text { Muğla, Ağla, Köyceğiz, Kartal gölün kuzey ve güney yamaçları, } 1810 \mathrm{~m} \text {, serpan- } \\
\text { tin, amfiolit kayaç açıklıkları, T. Uysal } 4317 \text { \& A. Aksoy }\end{array}$ \\
\hline Botryanthus & M. nazimiyensis Yıld. \& Kılıç & Tunceli, Tunceli-Erzincan yolu, Nazimiye, Yiğitler mevkii, T. Uysal 4254 \& A. Aksoy \\
\hline Botryanthus & M. pallens (M. Bieb.) Fisch. & Van, Gevaş, Göründü köyü, gölün güneydoğu yamaçları, T. Uysal 4261 \& A. Aksoy \\
\hline Botryanthus & M. pamiryigidii Eker & Bolu, Mudurnu, Örencik yaylası, vericiye doğru, 1550-1820 m, T. Uysal 4343 \\
\hline Botryanthus & M. inundatum Yıldırım \& Eker & $\begin{array}{l}\text { Hatay, Kisecik köyü, Aşağı Sorgun yaylası, radarın doğusu, çayırlık 1slak dere } \\
\quad \text { kenarları, 1350-1450m, T. Uysal } 4292 \text { \& A. Aksoy }\end{array}$ \\
\hline Botryanthus & M. fatmacereniae Eker & $\begin{array}{l}\text { Adana, Tufanbeyli-Saimbeyli yolu, Tufanbeyli'den Saimbeyli'ye doğru 10-15km } \\
\text { kala, yolun solunda kalan orman açıklıkları, } 1550 \mathrm{~m}, \text { T. Uysal } 4234\end{array}$ \\
\hline
\end{tabular}

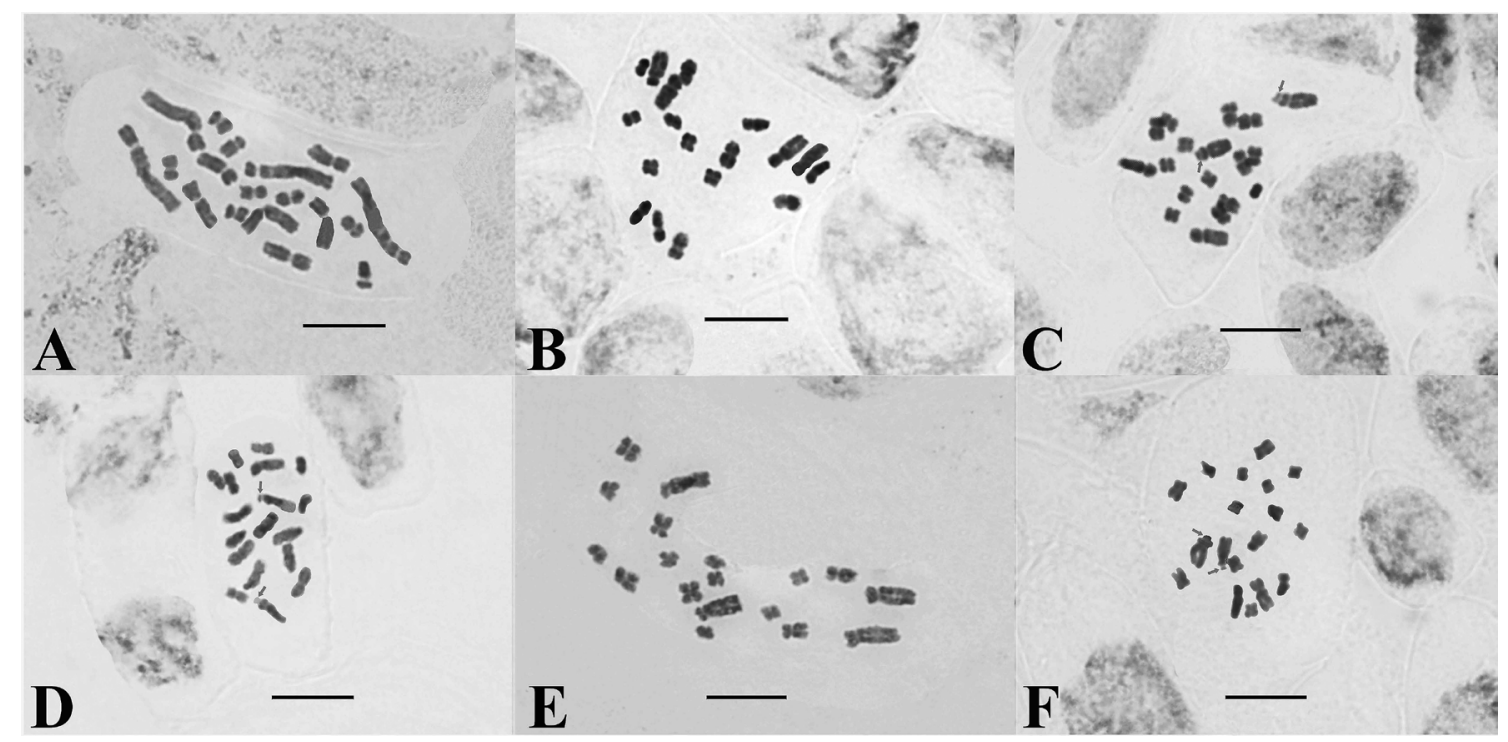

Fig. 1. Mitotic metaphase chromosomes of Muscari taxa. A: M. muglaensis, B: M. nazimiyensis, C: M. pallens, D: M. pamiryigidii, E: M. inundatum, F: M. fatmacereniae. Scale bar $=10 \mu \mathrm{m}$.

$24 \mathrm{~h}$. For dyeing, the tips were hydrolyzed in $5 \mathrm{MHCl}$ for one hour at room temperature and stained with $1 \%$ aceto-orcein prepared by adding $45 \%$ acetic acid. After obtaining the best metaphase image, chromosome pictures were taken with an Olympus DP72 digital camera mounted on an Olympus BX53 microscope. Karyotype measurements were performed on the photographed metaphase chromosome images with the KAMERAM program (KAMERAM 122, Argenit, İstanbul, Turkey) and karyomorphologies were determined using various symmetry indices. According to Levan et al. (1964), the morphologies of the chromosomes were named. According to Zarco (1986), Paszko (2006), and Peruzzi and Eroğlu (2013), karyotype measurements and symmetry index calculations were made.

\section{Results}

Karyotype analysis of six Muscari species, five of which were first, was performed. Metaphase plates and karyotypes of species belonging to the Muscari are shown in Figs. 1 and 2. In addition, the karyomorphological details of the species are listed in Tables 2 and 3.

M. muglaensis is a locally endemic species known from southwestern Anatolia. The chromosome number and morphology of the species were determined for the first time. M. muglaensis is a diploid species with $2 n=18$ chromosomes. The basic chromosome number is $x=9$. Karyotypes are composed of metacentric, submetacentric, and subtelocentric chromosomes. The karyotype formula is $10 \mathrm{~m}+4 \mathrm{sm}+4 \mathrm{st}$. The smallest chromosome of the species is $3.04 \mu \mathrm{m}$ and the largest chromosome is $12.17 \mu \mathrm{m}$. The total haploid chromosome length is $55.00 \mu \mathrm{m}$. Among the karyotype asymmetry indices of this species, the $\mathrm{CV}_{\mathrm{CL}}$ and $\mathrm{CV}_{\mathrm{CI}}$ are 52.56 and 23.28, respectively. Other chromosomal measurements and symmetry indices are given in Tables 2 and 3.

M. nazimiyensis is a locally endemic species known from eastern Anatolia. The chromosome number and morphology of the species were determined for the first time. M. nazimiyensis is a diploid species with $2 n=18$ chromosomes. The basic chromosome number is $x=9$. Karyotypes consist of metacentric and submetacentric chromosomes. The karyotype formula is $14 \mathrm{~m}+4 \mathrm{sm}$. The smallest chromosome of the species is $2.01 \mu \mathrm{m}$ and the largest chromosome is $5.13 \mu \mathrm{m}$. The total haploid chromosome length is $29.85 \mu \mathrm{m}$. Among the karyotype asymmetry indices of this species, the $\mathrm{CV}_{\mathrm{CL}}$ and $\mathrm{CV}_{\mathrm{CI}}$ 


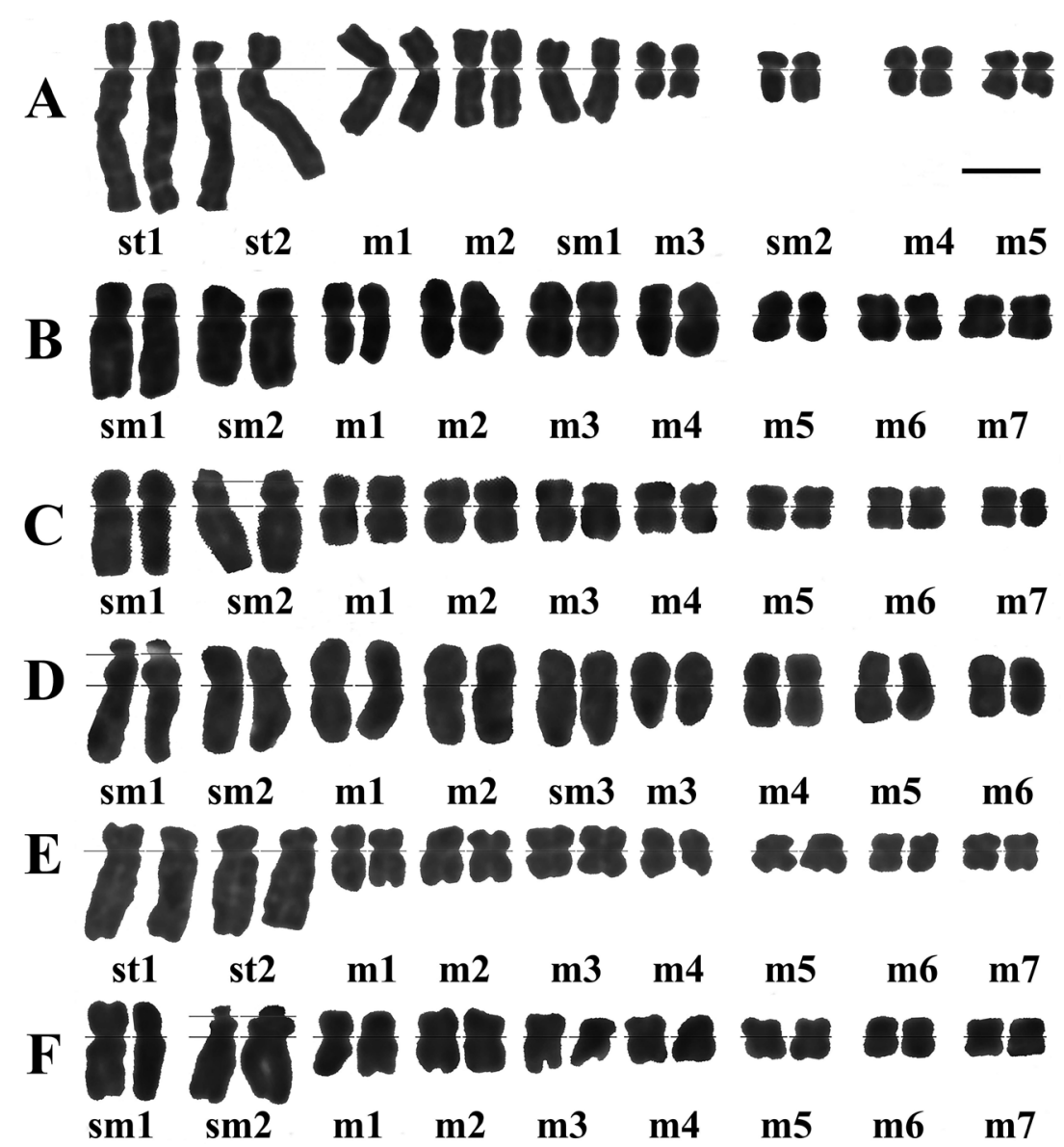

Fig. 2. Karyograms of Muscari taxa. A: M. muglaensis, B: M. nazimiyensis, C: M. pallens, D: M. pamiryigidii, E: M. inundatum, F: M. fatmacereniae. Scale bar $=10 \mu \mathrm{m}$.

Table 2. The chromosome features of Muscari taxa.

\begin{tabular}{lccccccccc}
\hline \hline \multicolumn{1}{c}{ Taxa } & $2 n$ & $\begin{array}{c}\mathrm{R} \mathrm{SC}-\mathrm{LC} \\
(\mu \mathrm{m})\end{array}$ & $\mathrm{R}-\mathrm{LC} / \mathrm{SC}$ & $\begin{array}{c}\mathrm{p}(\mu \mathrm{m}) \\
\mathrm{mean}( \pm \mathrm{SD})\end{array}$ & $\begin{array}{c}\mathrm{q}(\mu \mathrm{m}) \\
\mathrm{mean}( \pm \mathrm{SD})\end{array}$ & $\begin{array}{c}\mathrm{CL}(\mu \mathrm{m}) \text { mean } \\
( \pm \mathrm{SD})\end{array}$ & $\begin{array}{c}\mathrm{TCL} \\
(\mu \mathrm{m})\end{array}$ & $\begin{array}{c}\mathrm{CI} \\
\text { mean }( \pm \mathrm{SD})\end{array}$ & $\mathrm{KF}$ \\
\hline M. muglaensis & 18 & $3.04-12.17$ & 4.00 & $2.03( \pm 0.66)$ & $4.09( \pm 2.71)$ & $6.11( \pm 3.21)$ & 55.00 & $37( \pm 0.09)$ & $10 \mathrm{~m}+4 \mathrm{sm}+4 \mathrm{st}$ \\
M. nazimiyensis & 18 & $2.01-5.13$ & 2.55 & $1.31( \pm 0.25)$ & $2.01( \pm 0.84)$ & $3.32( \pm 1.00)$ & 29.85 & $41( \pm 0.07)$ & $14 \mathrm{~m}+4 \mathrm{sm}$ \\
M. pallens & 18 & $1.77-4.80$ & 2.71 & $1.20( \pm 0.29)$ & $1.73( \pm 0.80)$ & $2.92( \pm 1.08)$ & 26.32 & $43( \pm 0.05)$ & $14 \mathrm{~m}+4 \mathrm{sm}$ \\
M. pamiryigidii & 18 & $2.34-4.96$ & 2.11 & $1.47 \pm 0.24)$ & $2.09( \pm 0.61)$ & $3.56( \pm 0.81)$ & 32.02 & $42( \pm 0.04)$ & $12 \mathrm{~m}+6 \mathrm{sm}$ \\
M. inundatum & 18 & $2.15-6.58$ & 3.06 & $1.26( \pm 0.19)$ & $2.26( \pm 1.42)$ & $3.52( \pm 1.56)$ & 31.70 & $40( \pm 0.09)$ & $14 \mathrm{~m}+4 \mathrm{st}$ \\
M. fatmacereniae & 18 & $1.67-4.40$ & 2.64 & $1.12( \pm 0.20)$ & $1.66( \pm 0.69)$ & $2.78( \pm 0.88)$ & 25.05 & $42( \pm 0.05)$ & $14 \mathrm{~m}+4 \mathrm{sm}$ \\
\hline
\end{tabular}

R: Range, SC: shortest chromosome length, LC: longest chromosome length, p: mean length of the short arm, q: mean length of the long arm, CL: mean chromosome length, TCL: total haploid complement length, CI: mean centromeric index, SD: standard deviation, KF: karyotype formula, m: metacentric, sm: submetacentric, st: subtelocentric.

Table 3. The karyotype indices of Muscari taxa.

\begin{tabular}{lcccccc}
\hline \hline \multicolumn{1}{c}{ Taxa } & $\mathrm{A}_{1}$ & $\mathrm{~A}_{2}$ & $\mathrm{CV}_{\mathrm{CL}}$ & $\mathrm{CV}_{\mathrm{Cl}}$ & $\mathrm{AI}$ & $\mathrm{M}_{\mathrm{CA}}$ \\
\hline M. muglaensis & 0.38 & 0.52 & 52.56 & 23.28 & 12.24 & 33.66 \\
M. nazimiyensis & 0.28 & 0.30 & 30.21 & 16.59 & 5.01 & 21.08 \\
M. pallens & 0.24 & 0.36 & 36.90 & 11.37 & 4.19 & 18.08 \\
M. pamiryigidii & 0.26 & 0.22 & 22.87 & 10.61 & 2.43 & 17.41 \\
M. inundatum & 0.30 & 0.44 & 44.42 & 23.37 & 10.38 & 28.4 \\
M. fatmacereniae & 0.26 & 0.31 & 31.45 & 12.67 & 3.98 & 19.42 \\
\hline
\end{tabular}

$\mathrm{A}_{1}$ : Intrachromosomal asymmetry index, $\mathrm{A}_{2}$ : interchromosomal asymmetry index, $\mathrm{CV}_{\mathrm{CL}}$ : coefficient of variation of chromosome length, $\mathrm{CV}_{\mathrm{CI}}$ : coefficient of variation of the centromeric index, $\mathrm{AI}$ : karyotype asymmetry index, $\mathrm{M}_{\mathrm{CA}}$ : mean centromeric asymmetry. 
are 30.21 and 16.59 , respectively. Other chromosomal measurements and symmetry indices are given in Tables 2 and 3.

The chromosome number of $M$. pallens species has been reported as $2 n=18$ and 36 (Stuart 1970, Magulaev 1992, Gadnidze et al. 1998). In this study, the chromosome number of the species was determined as $2 n=18$. The basic chromosome number is $x=9$. Karyotypes consist of metacentric and submetacentric chromosomes. The karyotype formula is $14 \mathrm{~m}+4 \mathrm{sm}$. The smallest chromosome of the species is $1.77 \mu \mathrm{m}$, and the largest chromosome is $4.80 \mu \mathrm{m}$. The total haploid chromosome length is $26.32 \mu \mathrm{m}$. Satellites were observed in one chromosome pair and at the short arms of the second large chromosome. Among the karyotype asymmetry indices of this species, the $\mathrm{CV}_{\mathrm{CL}}$ and $\mathrm{CV}_{\mathrm{CI}}$ are 36.90 and 11.37, respectively. Other chromosomal measurements and symmetry indices are given in Tables 2 and 3 .

M. pamiryigidii is a locally endemic species known from northwest Anatolia. The chromosome number and morphology of the species were determined for the first time. M. pamiryigidii is a diploid species with $2 n=18$ chromosomes. The basic chromosome number is $x=9$. Karyotypes consist of metacentric and submetacentric chromosomes. The karyotype formula is $12 \mathrm{~m}+6 \mathrm{sm}$. The smallest chromosome of the species is $2.34 \mu \mathrm{m}$ and the largest chromosome is $4.96 \mu \mathrm{m}$. The total haploid chromosome length is $32.02 \mu \mathrm{m}$. Satellites were observed in one chromosome pairs and at the short arms of the first large chromosomes. Among the karyotype asymmetry indices of this species, the $\mathrm{CV}_{\mathrm{CL}}$ and $\mathrm{CV}_{\mathrm{CI}}$ are 22.87 and 10.61 , respectively. Other chromosomal measurements and symmetry indices are given in Tables 2 and 3.

$M$. inundatum is a locally endemic species known from southern Anatolia. The chromosome number and morphology of the species were determined for the first time. M. inundatum is a diploid species with $2 n=18$ chromosomes. The basic chromosome number is $x=9$. Karyotypes consist of metacentric and subtelocentric chromosomes. The karyotype formula is $14 \mathrm{~m}+4 \mathrm{st}$. The smallest chromosome of the species is $2.01 \mu \mathrm{m}$ and the largest chromosome is $5.13 \mu \mathrm{m}$. The total haploid chromosome length is $31.70 \mu \mathrm{m}$. Among the karyotype asymmetry indices of this species, the $\mathrm{CV}_{\mathrm{CL}}$ and $\mathrm{CV}_{\mathrm{CI}}$ are 44.42 and 23.37, respectively. Other chromosomal measurements and symmetry indices are given in Tables 2 and 3.

M. fatmacereniae is a locally endemic species known from southern Anatolia. The chromosome number and morphology of the species were determined for the first time. M. fatmacereniae is a diploid species with $2 n=18$ chromosomes. The basic chromosome number is $x=9$. Karyotypes consist of metacentric and submetacentric chromosomes. The karyotype formula is $14 \mathrm{~m}+4 \mathrm{sm}$. The smallest chromosome of the species is $1.67 \mu \mathrm{m}$ and the largest chromosome is $4.40 \mu \mathrm{m}$. The total haploid chro- mosome length is $25.05 \mu \mathrm{m}$. Satellites were observed in one chromosome pair and at the short arms of the second large chromosome. Among the karyotype asymmetry indices of this species, the $\mathrm{CV}_{\mathrm{CL}}$ and $\mathrm{CV}_{\mathrm{CI}}$ are 31.45 and 12.67 , respectively. Other chromosomal measurements and symmetry indices are given in Tables 2 and 3.

\section{Discussion}

In the genus Muscari, most species are diploid, with a basic chromosome number of $x=9$ and a chromosome number of $2 n=18$ (Stuart, 1970, Karlén 1984b, Dalgı̧̣ 1991, Özhatay and Johnson 1996, Johnson and Brandham 1997, Demirci Kayıran and Özhatay 2017, Bozkurt 2020, Kiran et al. 2020a, b). The current study confirms the former reports for all studied species. Metacentric and submetacentric chromosomes are seen as more common in studied species. Satellites have been observed in M. pallens, M. pamiryigidii and M. fatmacereniae and are minute as reported in previous studies (Demirci Kayıran and Özhatay 2017, Kiran et al. 2020a).

Eker et al. (2020) reported that M. muglaensis is morphologically similar to $M$. weissii, M. comosum, M. cycladicum and M. elmasii, but differs mainly by its large bulbs and fruit structure from $M$. weissii and M. comosum, and long pedicels of fertile flowers and transversely growing raceme in fruit from M. cycladicum and M. elmasii. Besides with the morphological differences, we can easily declare that karyotypes of this endemic species are seen quitely distinct from M. weissii, M. comosum, and M. elmasii (Table 4; Demirci Kayıran and Özhatay 2017, Kiran et al. 2020a).

Yıldırımlı and Kılıç (2019) reported that M. nazimiyensis is closely related to $M$. inconstrictum and M. aucheri, but differs by its shorter fertile flowers from M. inconstrictum, smaller capsule and linear leaves from M. aucheri. Karlén (1984a) reported that there is a more or less continuous decrease in length in the five longer $\mathrm{m}$ to sm pairs and the short pairs are $\mathrm{m}$ to $\mathrm{sm}$. In addition to, he reported that the satellite is the situation on the short arm of one of the chromosomes in the first pair. Demirci Kayıran and Özhatay (2017) reported the karyotype of M. aucheri as $2 n=12 \mathrm{~m}+4 \mathrm{sm}+2 \mathrm{st}$. We can say that $M$. nazimiyensis differs from $M$. inconstrictum and $M$. aucheri in terms of karyological features. Especially, the species has two fairly long sm, four medium $\mathrm{m}$, and finally three small $\mathrm{m}$ chromosomes.

Eker (2019b) reported that Muscari pamiryigidii is similar to M. armeniacum, M. aucheri, and M. bourgaei, but is easily distinguished from them by its shorter stems, dark brown outer tunics, prominently veined humistrate, and spreading leaves. As with suitable this morphological differences, karyotypes of this endemic species are seen quite comparing to M. armeniacum, M. aucheri and M. bourgaei (Table 4; Karlén 1984b, Demirci Kayıran and Özhatay 2017, Kiran et al. 2020b) 
Table 4. Comparison of the results with the previously reported karyotype formulas for Muscari taxa.

\begin{tabular}{|c|c|c|}
\hline Taxa & Karyotype formula & References \\
\hline M. muglaensis & $10 \mathrm{~m}+4 \mathrm{sm}+4 \mathrm{st}$ (diploid) & in this study \\
\hline \multirow[t]{2}{*}{ M. comosum } & $14 m+2 s m+2 t$ (diploid) & Kiran et al. (2020a) \\
\hline & $10 m+6 s m+2 s t$ (diploid) & Demirci Kayıran and Özhatay (2017) \\
\hline M. weissii & $12 \mathrm{~m}+2 \mathrm{sm}+4 \mathrm{st}$ (diploid) & Kiran et al. (2020a) \\
\hline M. elmasii & $14 m+4$ st (diploid) & Kiran et al. (2020a) \\
\hline M. pamiryigidii & $12 m+6 s m$ & in this study \\
\hline \multirow[t]{2}{*}{ M. aucheri } & $2 \mathrm{M}+12 \mathrm{~m}+4 \mathrm{sm}$ & Kiran et al. (2020b) \\
\hline & $12 \mathrm{~m}+4 \mathrm{sm}+2 \mathrm{st}$ & Demirci Kayıran and Özhatay (2017) \\
\hline \multirow[t]{3}{*}{ M. armeniacum } & $12 \mathrm{~m}+4 \mathrm{sm}+2 \mathrm{st}^{\mathrm{SAT}}, 12 \mathrm{~m}+4 \mathrm{sm}+2 \mathrm{st}$ & Demirci Kayıran and Özhatay (2017) \\
\hline & $n=7 \mathrm{~m}+2 \mathrm{sm}$ & Karlén (1984b) \\
\hline & $2 \mathrm{M}+14 \mathrm{~m}+2 \mathrm{sm}$ & Kiran et al. (2020b) \\
\hline M. bourgaei & $2 \mathrm{st}+2 \mathrm{st}^{\mathrm{SAT}}+14 \mathrm{~m}$ & Karlén (1987) \\
\hline M. inundatum & $14 m+4 s t$ & in this study \\
\hline \multirow[t]{9}{*}{ M. neglectum } & $4 \mathrm{~m}+10 \mathrm{sm}+4 \mathrm{st}^{\mathrm{SAT}}$ (diploid) & Demirci Kayıran and Özhatay (2017) \\
\hline & $16 \mathrm{~m}+12 \mathrm{sm}+8 \mathrm{st}$ (tetraploid) & Demirci Kayıran and Özhatay (2017) \\
\hline & $35 \mathrm{~m}+\mathrm{m}^{\mathrm{SAT}}+18 \mathrm{sm}$ & Demirci Kayıran and Özhatay (2017) \\
\hline & 36m+18sm (hexaploid) & \\
\hline & $n=4 \mathrm{~m}+5 \mathrm{sm}$ (diploid, tetraploid, hexaploid, octaploid) & Karlén (1984b) \\
\hline & $\begin{array}{l}13 \mathrm{~m}+11 \mathrm{sm}+2 \mathrm{st}+\mathrm{t}, 23 \mathrm{~m}+3 \mathrm{sm}, 21 \mathrm{~m}+5 \mathrm{sm}, 16 \mathrm{~m}+9 \mathrm{sm}+\mathrm{t} \text { or } 16 \mathrm{~m}+7 \mathrm{sm}, 13 \mathrm{~m}+9 \mathrm{sm}+\mathrm{st} \\
17 \mathrm{~m}+5 \mathrm{sm}+\mathrm{st} \text { (aneuploidy) }\end{array}$ & Jafari et al. (2008) \\
\hline & $17 \mathrm{~m}+5 \mathrm{sm}+\mathrm{st}$ (autopentaploid) & Jafari et al. (2008) \\
\hline & $14 \mathrm{~m}+3 \mathrm{sm}$ (tetraploid) & Jafari et al. (2008) \\
\hline & $2 \mathrm{M}+28 \mathrm{~m}+6 \mathrm{sm}$ (diploid) & Kiran et al. (2020b) \\
\hline
\end{tabular}

Eker and Yildirım (2021) reported that M. inundatum is morphologically similar to M. neglectum and M. adilii, but differs mainly by its shouldered fertile flowers with erect to slightly recurved lobes at maturity. Karyotypes of this endemic species are quite distinct from $M$. neglectum (Table 4; Karlén 1984b, Jafari et al. 2008, Demirci Kayıran and Özhatay 2017, Kiran et al. 2020b).

Eker (2019a) reported that M. fatmacereniae is similar to $M$. armeniacum and $M$. botryoides, but the former is easily distinguished from both latter species by its shouldered and strongly constricted flowers; blackishbrown outer tunics; gracile, mostly flat erect leaves; and lax raceme. As concerning M. botryoides, Karlén (1984b) reported that the idiogram consists of two pairs of long st chromosomes, three pairs of medium-sized $\mathrm{m}$ to sm pairs and four pairs of short $\mathrm{m}$ to sm chromosomes. In addition, he reported that the satellites are situated on the short arms of the second pair. Kiran et al. (2020b) reported the karyotype of M. botryoides as $14 \mathrm{~m}+2 \mathrm{sm}+2 \mathrm{sm}^{\mathrm{SAT}}$. Therefore, we can interpret the karyotypes of this endemic species are partly similar to M. armeniacum in terms of having $7 \mathrm{~m}$ and $2 \mathrm{sm}$ chromosomes (Table 4 for $M$. armeniacum; Karlén 1984a, b, Demirci Kayıran and Özhatay 2017, Kiran et al. 2020b).

Demirci Kayıran and Özhatay (2017) reported that the TCL of the taxa in the subgenus Leopoldia varied from 40 to $56 \mu \mathrm{m}$. Also, they reported that the TCL of the species in the subgenus Botryanthus ranged from 22 to $35 \mu \mathrm{m}$. Kiran et al. (2020a) reported that the TCL of 11 species in the subgenus Leopoldia ranged from 44 to $67 \mu \mathrm{m}$. In addition, Kiran et al. (2020b) reported that the TCL of the taxa in the subgenus Botryanthus varied from 24 to $32 \mu \mathrm{m}$. The TCL value of the M. muglaensis (TCL:
$55 \mu \mathrm{m})$, which is a member of the Leopoldia, is compatible with the values. The TCL values (TCL: 25-32 $\mu \mathrm{m}$ ) of the M. nazimiyensis, M. pallens, M. pamiryigidii, M. inundatum and $M$. fatmacereniae in the subgenus Botryanthus is compatible with the previously declared information. As consistent with former reports, The TCL values for Botryanthus taxa are smaller than Leopoldia taxa (Demirci Kayıran and Özhatay 2017, Kiran et al. 2020a, b). Regarding karyomorphological aspects, symmetrical karyotypes have been considered as less derived and asymmetrical karyotypes as the more derived ones (Stebbins 1971). $\mathrm{CV}_{\mathrm{CI}}$ is a parameter that indicates heterogeneity of the centromeric index. Our results showed that $\mathrm{CV}_{\mathrm{CI}}$ values ranged from 10 to $23 . \mathrm{CV}_{\mathrm{CL}}$ shows different chromosome lengths of a complement. The $\mathrm{M}_{\mathrm{CA}}$ index used to measure intrachromosomal asymmetry correlates with $\mathrm{CV}_{\mathrm{CL}}$. Our results indicated that both $\mathrm{CV}_{\mathrm{CL}}$ and $\mathrm{M}_{\mathrm{CA}}$ have the highest value in M. muglaensis. Bentzer (1973) reported that the Aegean representatives of Leopoldia are in an active phase of evolution and show considerable morphological variation as well as polyploidization. We can say that M. muglaensis, which has the most asymmetrical karyotypes and highest karyotype indices among all examined species, is a derived species.

\section{Acknowledgements}

I would like to thanks a lot for the foundation Tubitak (the project number 117Z222) because of its financial support. 


\section{References}

Azizi, N., Amirouche, R. and Amirouche, N. 2016. Karyological investigations and new chromosome number reports in Bellevalia Lapeyrouse, 1808 and Muscari Miller, 1758 (Asparagaceae) from Algeria. Comp. Cytogenet. 10: 171-187.

Bentzer, B. 1972. Structural chromosome polymorphism in diploid Leopoldia weissii Freyn ex Heldr. (Liliaceae). Bot. Not. 125: 180-185.

Bentzer, B. 1973. Taxonomy, variation and evolution in representatives of Leopoldia Parl. (Liliaceae) in the southem and central Aegean. Bot. Not. 126: 69-132.

Bozkurt, M. 2020. Karyological analysis of endemic five Muscari taxa. Cytologia 85: 289-294.

Böhnert, T. and Lobin, W. 2017. Leopoldia neumannii sp. nov. (Asparagaceae, Scilloideae): A new species of Muscari sensu lato from Greece. Willdenowia 47: 179-185.

Dalgıç, G. 1991. Cytotaxonomic studies on the genus Muscari in European Turkey. Bot. Chronika 10: 819-825.

Davis, P. H. and Stuart, D. C. 1980. Muscari Mill. In: Tutin, T.G., Heywood, V.H. and Valentine, D.H. (eds.), Flora Europaea, Vol. 5. Cambridge University Press, London, UK. pp. 46-49.

Davis, P. H. and Stuart, D. C. 1984. Muscari Mill. In: Davis, P. H. (ed.). Flora of Turkey and the East Aegean Islands 8. Edinburgh University Press, Edinburgh. pp. 245-263.

Demirci, S., Özhatay, N. and Koçyiğit, M. 2013. Muscari erdalii (Asparagaceae, Scilloideae), a new species from Southern Turkey. Phytotaxa 154: 38-46.

Demirci, S., Özhatay, N., Gürdal, B. and Kaya, E. 2014. Contributions to the Turkish Geophyte Flora. In: Kaya, E. (ed.) Muscari Mill. Türkiye Geofitleri 2. Atatürk Bahçe Kültürleri Merkez Araştırma Enstitüsü, Yayın No: 96, Yalova. pp. 543-550. (in Turkish).

Demirci Kayıran, S. and Özhatay, F. N. 2017. A karyomorphological study on the genus Muscari Mill. growing in Kahramanmaraş (Turkey). Turk. J. Bot. 41: 289-298.

Demirci Kayıran, S., Özhatay, N. and Kaya, E. 2019. Muscari tauricum (Asparagaceae, Scilloideae), a new species from Turkey. Phytotaxa 399: 109-118.

Doğu, S. and Uysal, T. 2019. Muscari savranii (Asparagaceae), A New species from central Anatolia, Turkey. Phytotaxa 402: 155-164.

Eroğlu, H. E., Şimşek, N., Koç, M. and Hamzaoğlu, E. 2013. Karyotype analysis of some Minuartia L. (Caryophyllaceae) taxa. Plant Syst. Evol. 299: 67-73.

Eroğlu, H. and Pınar, S. M. 2019. The taxonomic resurrection of Muscari haradjianii (Asparagaceae, Scilloideae), and a new synonym in the genus Muscari in Turkey. Phytotaxa 418: 97-106.

Eroğlu, H., Pınar, S. M. and Fidan, M. 2019. Muscari sabihapinari sp. nov. (Asparagaceae) from Anatolia, Turkey. Nord. J. Bot. 37: 02514 .

Eker, İ. 2012. Muscari Mill. In: Güner, A., Aslan, S., Ekim, T., Vural, M. \& Babaç, M.T. (eds.), Türkiye Bitkileri Listesi (Damarlı Bitkiler). Nezahat Gökyiğit Botanik Bahçesi ve Flora Araştırmaları Derneği Yayını, İstanbul, pp. 98-100. (in Turkish).

Eker, İ. 2019a. Muscari fatmacereniae (Asparagaceae, Scilloideae), a new species from southern Anatolia. Phytotaxa 397: 99-106.

Eker, İ. 2019b. Muscari pamiryigidii (Asparagaceae, Scilloideae), a new species from northwestern Anatolia. Phytotaxa 408: 255-266.

Eker, İ. 2021. What is Muscari massayanum and what is not? Second species born of confusion: Muscari erzincanicum (Asparagaceae, Scilloideae), a new species from Turkey. Phytotaxa 487: 41-055.

Eker, İ., Duman, H. and Yıldırım, H. 2020. Muscari muglaensis (Asparagaceae, Scilloideae), a new species from southwestern Anatolia. Phytotaxa 475: 267-278.
Eker, İ. and Kandemir, A. 2020. Taxonomic resurrection of Muscari sintenisii Freyn (Asparagaceae) and lectotypification of the species. Bağbahçe Bilim Dergisi 7: 12-24. (in Turkish)

Eker, İ. and Yıldırım, H. 2021. Muscari inundatum (Asparagaceae, Scilloideae), a new species from southern Anatolia. Phytotaxa 484: 181-194.

Eker, İ., Yıldırım, H. and Armağan, M. 2019. Türkiye Florası İçin Yeni Bir Müşürüm Kaydı: Muscari pallens (M.Bieb.) Fisch. (Kuşkonmazgiller/Asparagaceae). Bağbahçe Bilim Dergisi 6: 45-53. (in Turkish)

Garbari, F. 1966. Contributo Allo Studio Citologico dei Muscari Italiani. Caryologia 19: 419-428.

Garbari, F. 1972. Note sul genere Pseudomuscari (Liliaceae). Webbia 27: $369-381$.

Garbari, F. 1973. Le specie del genere Leopoldia Parl. (Liliaceae) in Italia. Webbia 28: 57-80.

Garbari, F. and Greuter, W. 1970. On the taxonomy and typification of Muscari Miller (Liliaceae) and allied genera, and on the typification of generic names. Taxon 19: 329-335.

Gadnidze, R. I., Gviniashvili, T. N., Danelia, I. M. and Churadze, M. V. 1998. Chromosome numbers of the species of the Georgian flora. Bot. Zhurn. 83: 143-147.

Goldblatt, P. 1996. Index to plant chromosome numbers 1992-1993. Monographs in Systematic Botany from the Missouri Botanical Garden. 58: 1-276.

Jafari, A., Maassoumi, A. A. and Farsi, M. 2008. Karyological study on Bellevalia and Muscari (Liliaceae) species of Iran. Asian J. Plant Sci. 7: 50-59.

Johnson, M. A. T. and Brandham, P. E. 1997. New chromosome numbers in petaloid monocotyledons and in other miscellaneous angiosperms. Kew Bull. 52: 121-138.

Karlén, T. 1984a. Muscari pulchellum (Liliaceae) and associated taxa in Greece and W Turkey. Willdenowia 14: 89-118.

Karlén, T. 1984b. Karyotypes and chromosome numbers of five species of Muscari (Liliaceae). Willdenowia 14: 313-320.

Karlén, T. 1987. Muscari sandrasicum (Liliaceae), a new species from Turkey. Willdenowia 16: 375-382.

Karlén, T. 1991. Muscari Miller. In: Strid, A. and Tan, K. (eds.), Mountain Flora of Greece, Vol. 2. Edinburgh Univ. Press, Edinburgh. pp. 697-701.

Kaya, E. and Rastgeldi, U. 2014. Muscari Mill. In: Kaya, E. (ed.), Türkiye Geofitleri. Vol. 2. - Furkan Ofset, Yalova. pp. 338-411.

Kiran, Y., Pınar, S. M., Dogan, G. and Eroğlu, H. 2020a. A karyomorphological study on the subgenus Leopoldia of the genus Muscari growing in Turkey. Cytologia 85: 79-83.

Kiran, Y., Pınar, S. M., Dogan, G. and Eroğlu, H. 2020b. A karyomorphological study on the genus Muscari Miller growing in Turkey. Cytologia 85: 301-305.

Levan, A., Fredga, K. and Sandberg, A. A. 1964. Nomenclature for centromeric position on chromosomes. Hereditas 52: 201-220.

Magulaev, A. Y. 1992. Chromosome numbers in some species of vascular plants of the northern Caucasus flora. Bot. Zhurn. 77: $88-90$.

Marques de Resende, K. F. 2017. Karyotype Evolution: Concepts and Applications. In: Bhat, T. A. and Aijaz Ahmad Wani, A. A. (eds.), Chromosome Structure and Aberrations. Springer India, New Delhi. pp. 181-200.

Özhatay, N. and Johnson, M. 1996. Some karyological remarks on Turkish Allium sect. Allium, Bellevalia, Muscari, Ornithogalum subg. Ornithogalum. Bocconea 5: 239-249.

Paszko, B. 2006. A critical review and a new proposal of karyotype asymmetry indices. Plant Syst. Evol. 258: 39-48.

Peruzzi, L. and Eroğlu, H. E. 2013. Karyotype asymmetry: Again, how to measure and what to measure? Comp. Cytogenet. 7: 1-9.

Pınar, M. P., Fidan, M. and Eroğlu, H. 2018. Muscari botryoides (L.) Mill.: A new record for the family Asparagaceae from Turkey. 
Turk. J. Agric. Res. 5: 116-119. (in Turkish)

Pirhan, A. F., Yıldırım, H. and Altığlu, Y. 2014. Muscari serpentinicum sp. nova (Asparagaceae): A new species from western Anatolia, Turkey. Ot Sist. Bot. Dergisi 21: 1-14.

Ruiz-Rejón, M. 1978. Estudios cariológicos en especies españolas del orden Liliales. III. Familia Liliaceae. Ana. Inst. Bot. Cavanilles 34: 733-759.

Ruiz-Rejón, M. and Oliver, J. L. 1978. Números cromosómicos para la Flora española. Número 68: Scilla autumnalis; Número 69: Muscari atlanticum. Lagascalia 8: 113-117.

Ruiz-Rejón, M., Pascual, L., Ruiz-Rejón, C., Valdés, B. and Oliver, J. L. 1985. A new species of Muscari subgenus Leopoldia from the Iberian Peninsula. Biochem. Syst. Ecol. 13: 239-250.

Ruiz-Rejón, C., Lozano, R. and Ruiz-Rejón, M. 1986. Números cromosómicos para la flora española. Lagascalia 14: 273-304.

Speta, F. 1989. Muscari (subg. Leopoldia) mirum Speta, spec. nova, im kreise seiner nachsten verwandten. Phyton 29: 105-114.
Speta, F. 1998. Hyacithaceae. In: Kubitzki K, (ed.). The Families and Genera of Vascular Plants, Vol. 3. Springer-Verlag, Heidelberg. pp. 261-285.

Stebbins, G. L. 1971. Chromosomal Evolution in Higher Plants. Edward Arnold, London.

Stuart, D. C. 1970. Chromosome numbers in the genus Muscari. Notes R. Bot. Gard. Edinb. 30: 189-196.

Yildırım, H. 2015. Muscari atillae sp. nova (Asparagaceae): A new species from eastern Anatolia, Turkey. Phytotaxa 213: 291-295.

Yıldırım, H. 2016. Muscari elmasii sp. nova (Asparagaceae): A new species from western Anatolia, Turkey. Turk. J. Bot. 40: 380-387.

Yıldırımlı, Ş. and Kılıç, Ö. 2019. A new species of Muscari Mill. (Asparagaceae/Liliaceae), M. nazimiyensis from Tunceli, Turkey. Ot. Sist. Bot. Dergisi 26: 13-16.

Zarco, C. R. 1986. A new method for estimating karyotype asymmetry. Taxon 35: 526-530. 